\title{
Cooperation for Development, Brazilian Regional Leadership and Global Protagonism*
}

\author{
Leticia Pinheiro \\ Pontifícia Universidade Católica do Rio de Janeiro, Brazil \\ Gabrieli Gaio \\ Master's Candidate in African Studies, Universidade de Lisboa, Portugal
}

\begin{abstract}
This article aims to analyze Brazil's policy towards South America during Luiz Inácio "Lula" da Silva's government by discussing what kind of leadership the country was able to perform in the region during this time. The authors examine the role played by the policy of International Cooperation for Development on such regional leadership. The central argument is that although Brazil has performed the role of a regional leader, there is a need for distinguishing leadership for regional matters - inwards regional leadership - from leadership for global issues - outwards regional leadership. The article argues that inwards regional leadership was in fact successfully performed by Brazil in South America, mainly due to its role as a Development Leader. On the other hand, such leadership for regional matters did not always allow Brazil to act on behalf of the entire region on the global arena. Nevertheless, the Brazilian diplomacy left behind the belief that, in order to have global protagonism, the country should use South America as a regional launching platform. Instead, Brazil has been making use of global coalitions such as IBSA and BRICS to boost its global role.
\end{abstract}

Keywords: Brazil; South America; regional leadership; development; international cooperation.

\section{Introduction}

In the Brazilian Foreign Policy literature, the reference to the Brazilian pursuit of an important international role is not new. Indeed, this is one of the most recurrent aspects ascribed to the Brazilian diplomacy (LIMA, 2005b; SILVA, 1995). Another ever-present feature regarding Brazil's stance on the international scenario is its alleged drive for playing a

(*) $\quad$ http://dx.doi.org/10.1590/1981-38212014000100009

The authors would like to thank Diana Aguiar, Eduardo Plastino, Janina Onuki, Julimar Bichara, Luciano Barbosa de Lima, Maria Regina Soares de Lima, Monica Hirst, Monica Salomón, Pedro Archer, Tatiana Oliveira, Tiago Martins, Tim Power, and Yuri Tonani, who have helped with the research, suggestions and/or comments to improve their argument. We also thank the anonymous referees of this journal for their insightful comments and suggestions. Possible mistakes and omissions are the sole responsibility of the authors. 
leading role in the regional arena (SARAIVA, 2010; SILVA, 1995). This is also true as far as official statements are concerned. To give a recent example, former president Luiz Inácio "Lula" da Silva said before Itaipu Hydroelectric Board of Directors that there was a claim from the South American countries for Brazil to lead them ${ }^{1}$. Likewise, it is worth mentioning the critiques voiced by former minister of Foreign Affairs Luiz Felipe Lampreia (1995-2001), saying that leadership was something to put in practice, not to be heralded. Moreover, he claimed, leadership should be a continuous and consistent attitude ${ }^{2}$.

In our view, both the aim of having a more important international role and of exercising regional leadership are still very much present in the Brazilian foreign policy agenda. Nevertheless, recent changes on the Brazilian stance towards South America (HIRST, LIMA and PINHEIRO, 2010; LIMA and HIRST, 2006; PECEQUILO and CARMO, 2012; SARAIVA, 2010; SPEKTOR, 2010) should be taken into account in order to better evaluate each one of those aims, as well as their alleged connection, that is, the hypothesis that being a regional leader is a pre-requirement for having international protagonism. We argue that during Lula's government (2003-2010), the Brazilian policy of horizontal cooperation for development has strongly contributed to strengthen Brazilian regional leadership as well as to diminish - if not totally extinguish - the instrumental nature of the latter to achieve global protagonism ${ }^{3}$.

This paper joins the debate about Brazilian regional performance by starting with the question of what kind of leadership Brazil has played - if the country has indeed played such a role - and in which areas. Our main hypothesis is that one should distinguish between two different kinds of leadership: inwards regional leadership; and outwards regional leadership. Whilst the former is defined as the capacity to set formal or informal rules and patterns of behavior within the regional sphere; the latter is defined as the capacity to lead regional partners in global matters. In this sense, the thesis that Brazil was likely to consolidate itself as a middle global power before gaining acceptance as a leader in its region (MALAMUD, 2011) should be slightly revised. Although we follow the argument that "leading a region is not a precondition for global emergence" (Idem, p. 4), we argue, instead, that Brazil does play the role of a regional leader. In saying so, we contend that in particular issue areas Brazil fulfills the three necessary conditions that, according to Van Langenhove and Zwartjes (FORTHCOMING), qualify it to play an inwards leading role in South America: (i) the willingness to act as a leader; (ii) the leadership capacity; and, finally (iii) the acceptance of this kind of leadership by other actors. Finally, we argue that, although it is not necessary to be a representative of its own region to play a relevant role in the international scenario, Brazilian global protagonism is reinforced by its role as a Development Regional Leader.

To present our argument, we have organized this article in three sections. First, we briefly discuss distinct views of Brazil's regional leadership - or its lack - followed by our quest for a different approach to characterize leadership. Second, we address what kind of leadership Brazil has played in South America by means of implementing projects for development of two different types: credit lines for infrastructure projects ${ }^{4}$ and technical cooperation for social

1 Available at: <http://www.bbc.co.uk/portuguese/reporterbbc/story/2008/03/080303_ams_abre1_ diplomacia.shtml>. Accessed: 4 May 2012.

2 "Brasil já exercia liderança, diz ex-chanceler de FHC". Folha. com, 19/01/2003. Available at: <http://www1. folha.uol.com.br/folha/mundo/ult94u50530.shtml>. Accessed: 4 May 2012.

3 By region we refer to the group of South American states only.

4 It is important to underline that we are talking about public financing for foreign governments to purchase 
development policies. Altogether, these initiatives are strong indicators of Brazilian position as an inwards regional leader - a Development Regional Leader, label that captures and summarizes Brazil's willingness and capacity, as well as the recognition from its regional fellows, of Brazilian initiatives for boosting economic and social development in the region. In the third section, we turn to the place IBSA Dialogue Forum ${ }^{5}$ has occupied on Brazilian foreign policy during the Lula government and to its connection - if any - with Brazilian regional leadership as defined earlier. By way of conclusion, we raise some thoughts about the complementarity, though not dependence, between Brazilian regional leadership and Brazilian global protagonism.

\section{To be or not to be a regional leader}

The need for more precise categories is a central question for scholars and practitioners trying to qualify and rank countries in the international system. This is particularly more complicated when we talk about volatile attributes or situations. Leadership and power, for instance, are not static features. It is impossible to ascribe to anybody or to any country a kind of everlasting leadership position or major power situation. Those are relational and historically contingent categories, and therefore they are not only associated with the country's own capabilities and behavior - which are not static either - but also to other countrie's capabilities and behavior, and consequently to the current configuration of the international system. In face of the identification of a power shift in global politics from the G7 to a group of emerging powers (HURREL, 2000), this debate seems to have become even more intense.

It is very much due to the difficulties around the definition of those categories that authors from different perspectives have been trying either to rank or to label countrie's power - great power, middle power, intermediate power, emerging power, global power, regional power - as well as to label different kinds of leadership - multiple, collaborative, shared, distributive, by concertation ${ }^{6}$. By doing so, they attempt to simultaneously take into account some of the particularities of each country and to avoid excessive detailed classifications. The bad news is that either we have dozens of different - and sometimes useless - typologies or, rather, we surpass actual and relevant singularities in the name of parsimony.

Notwithstanding the acknowledgement of the relevance as well as the complexity of the attempts to conceptualize power, it is not our aim to propose a new definition or alternative criteria to categorize it. Instead, we have decided to join the debate about different kinds of

goods and services from Brazilian construction and engineering companies related to infrastructure projects that South American countries consider being relevant to their development. We are not interested in discussing the broader phenomenon of the expansion of Brazilian capital, a strategy that, though may also benefit from public finance support, does not necessarily aim to generate regional public goods such as infrastructure. For a discussion of the latter and its effects on national development, see Masiero and Caseiro (2012); for the international expansion of Brazilian capital, see Actis $(2012,2013)$.

5 From the outset, it is important to note that, although Brazil participates in other political coalitions with emerging countries and middle powers, such as the BRICS - Brazil, Russia, India, China and South Africa - and is even currently investing much more politically in the latter than in IBSA, the option to examine the place of the latter coalition in Brazil's foreign policy and its relation to the issue of its alleged regional leadership agenda (instead of the BRICS) was due to the fact that the article examines in particular the period of President Luis Inácio Lula da Silva's government (2002-2010), while the BRICS group was only formalized in the first presidential summit in 2009, that is, at the end of his second term.

6 "El desafío de definir el rol como potencia global" by Juan Gabriel Tokatlian. La Nacion, 6 November 2010. Available at: <http://www.lanacion.com.ar/1321624-el-desafio-de-definir-el-rol-como-potencia-global>. Accessed: 2 May 2012. 
leadership, due to the importance of this category for South American current international politics. Therefore, we see leadership as a position created and nurtured both by those who present themselves as leaders and by those within the same region and/or from abroad that reinforce, through statements or actions, the leading position of a country. Additionally, we argue that, when it comes to leadership, we have to think not only about who exercises it, but also about on which issues it is exercised.

As a volatile, and not structural, feature, a leading role has to be continuously renewed in order to be recognized as such. Indeed, when it comes to regional leadership, we see it as an ongoing process which can always be disputed by regional neighbors - in the South American case, usually by Brazil, Argentina and, more recently, Venezuela (FLEMES and WOJCZEWSKI, 2010). Therefore, we are not facing a Shakespearean dilemma of "to be or not to be" a leader; but rather a kind of Pirandelian puzzle of "So It Is (If You - [We] - Think So)". The main difference is in the way Brazil sees itself as a regional leader and the way it is seen as a leader by its peers, independently of the means through which this recognition is achieved and renewed.

Most authors agree with the idea that Brazil was not in a position that could lead to any easy or automatic acknowledgement of the country's regional leadership in world affairs (LIMA and HIRST, 2006); or of a consolidated regional leadership (VIEIRA, 2011); or even of a regional leading role at all (HIRST, 2010).

According to Andrés Malamud (2011), who has been dedicating close attention to this subject, leadership can be defined as "the capacity to engage subordinate states so that they adopt the goals of the leading state as their own" (2011, p.3, our emphasis). Contrarily, we do not refer to leadership in such a way, since we understand the idea of subordinate states adopting the goals of other state as their own as an example of dominance, rather than leadership ${ }^{7}$. In fact, the idea of subordination seems to detract or even to ignore a certain level of complementarity of interests and freewill, which can be identified in the case of Brazil and its regional fellows. Indeed, we argue that the kind of regional leadership Brazil has performed during the Lula government should be seen as associated to its capacity to be a referential country for development policies, not only because it was able to take more than 30 million people out of poverty in less than one decade (WORLD BANK, apud STOLTE, 2012, p.13), but also because it put in place a type of cooperation for development which served, even if asymmetrically, the actual interests of the South American countries, including Brazil. In this sense, leadership here is meant as a role of prominence within the region towards the common objective of development. Indeed, as stated by Dauvergene and Farias, "Brazil has moved beyond the 'traditional' role of calling for development to being in a position to draw on its own experience to offer development solutions" (2012, p. 909), thanks to the fact that both the relative paucity of resources for Brazil to assume the role of paymaster and therefore to absorb the costs of region building, and the lack of will to do so (BURGES, 2005, 2007, 2008) now belong to the past (SARAIVA, 2010).

Malamud also defines leadership as "the capacity to influence followers" (2011, p. 3). Even if we acknowledge that influence is a very difficult attribute to measure, this idea could help us to better understand the kind of leadership Brazil has actually played in the region. Even so, we should make a distinction between "the capacity to influence followers" (Idem) in

7 In saying so, we are implicitly denying Kindleberger's (1981) definition and distinction between the concepts of dominance and leadership. Whilst for him "one country... dominated another when the other had to take into account what the first entity did, but the first could equally ignore the second" (KINDLEBERGER, 1981, p. 243), and leadership is a situation when a country persuades "others to follow a given course of action which might not be in the follower's short-run interest if it were truly independent" (Ibidem); for us, such definitions of dominance and leadership do not take into account a certain level of complementarity of interests and freewill between leaders and supporters. 
regional matters and in global matters. In the case analyzed here, we witness a kind of leadership that can neither be extended to all issue areas, nor qualify the leading country to claim the right and legitimacy to represent its regional fellows in global issues. In sum, we are not talking about a kind of comprehensive leadership or structural leadership, that is, one that could cover all dimensions of a country's interests whichever the forum of discussion. In fact, we argue that this kind of leadership no longer exists (not even great powers can benefit from this kind of leadership). On the contrary, we have opted for examining only one dimension of Brazilian performance in the region, one that can be seen as an example of a kind of leadership.

Now we turn to the concept of consensual hegemony, as crafted by Burges (2008) in his attempt to explain the leadership strategy of an emerging power like Brazil - a strategy, he concludes, in which Brazil has not succeeded. (Idem, p. 66). This concept was meant to substitute the somewhat worn out concept of leadership, as well as to be a tool to explain a kind of strategy that, even if it fails to reach its objective, nevertheless "offers rewards that compensate for a failure to attain it". (Idem, p. 66) .

Differently from several theoretical perspectives that usually associate the idea of hegemony to a coercive behavior by the hegemon, the concept of consensual hegemony proposed by Burges focuses "on a Gramsci-inspired vision that privileges the creation of consensus through the constructive inclusion of potentially competing priorities and the shaping of common positive outcomes" (Idem, p. 81).

Despite offering new ways to think about the particular characteristics of Brazilian behavior in South America, we do not subscribe entirely to Burge's conclusions, and indeed we take some of them as misleading. Firstly, we do not agree with the low importance Burges (2008) gives to the self-interest reasons of the South American countries on following the leader, which in the end he says can be rather apparent ${ }^{9}$. And secondly, when Burges (2008) separates the idea of hegemony and the idea of hegemon in two distinct entities - "hegemony remains the constant, overarching structure, with the role of hegemon shifting between the embraced states depending on which participant is best able to coordinate and advance a specific aspect of the project" (Idem, p. 74) - he gives the structure - hegemony - a rather autonomous existence, which we are not prepared to follow..

Nevertheless there are several other elements of Burge's thesis that are quite useful for what we are discussing in this article. For instance, some of his evidences on Brazil's increasing economic presence in the region, by means of private investment flows and public financing through BNDES; and moreover, his ideas that Brazil could be seen as a regionally predominant, but not a dominant state in South America (Idem, p. 74).

Having reviewed these contributions that scrutinize the concept of leadership for explaining the situation in South America, which have greatly helped us to refine our own view on the subject, we will now present our understanding of Brazilian regional leadership and offer some examples to illustrate it.

8 According to Burges, when the strategy fails "it demonstrates that the very attempt to form a consensual hegemony offers the leading state gains that can compensate for an ultimate failure in the larger project; the nondominating nature of consensual hegemony allows for a series of shifts in the nature of regional relations that at least partially embeds the leading state's interests." (BURGES, 2008, p. 66)

9 In his own words, "The dominant group will go to the extent of making minor or tangential sacrifices, even in the economic realm, in order to co-opt the subordinate, creating a system of political economy which subtly, yet indelibly, commits the subaltern to preserving the hegemony for what at first glance may appear self-interested reasons" (BURGES, 2008, p. 71). 


\section{Cooperation for development and Brazilian regional leadership}

Brazilian Cooperation Agency (BCA) - the official agency in charge of coordinating Brazilian policy of international cooperation - defines SSC as mainly technical cooperation, based on the commitment to the construction of capacities for sustainable development, by means of integrating the human resources formation, organizational strengthening, institutional development, and the provision of public goods (CINTRA, 2011). Moreover, BCA excludes financial transfers such as the ones performed by the BNDES (National Bank for Economic and Social Development) to other developing countries out of its definition. In this sense, SSC for development should not be seen as the same of SS relations in general, although "for Brazil [they] have become intertwined dimensions in its foreign affairs", as posited by Hirst (2011, p. 05). According to some scholars, Brazilian SSC for development is characterized by certain singularities, since the country perceives it as:

(A)n institutionally grounded action built upon the capabilities of its state agencies comprising technical assistance, skills transference and capacity building. It is centered upon the notion of inter-state partnership, based on ideals of solidarity, the relevance of shared experiences and the value of exchanging capabilities to overcome the social and economic limitations imposed by underdevelopment (HIRST, 2011, p. 04).

By a different token, we could take into account the study by Lengyel and Malacalza (2011), who have written a very interesting essay on the variety of instruments and forms through which this kind of cooperation can manifest itself. In their view, SSC can include not only non-refundable loans but also refundable financing, considering Government Sponsored Investments (GSI) as a modality of SSC. According to them, GSI are:

\footnotetext{
Investments sponsored/financed by governments and secured by bilateral agreements favorable to receptor countries, which do not impose real financial risks to the enterprises involved (...) and imply a relevant economic disbursement envisaging vital areas of development in the receptor countries. (LENGYEL and MALACALZA, 2011, p.11)
}

According to Lengyel \& Malacalza (2011), then, we could indeed take - though not without consequences - the credit lines for infrastructure projects in South America together with technical cooperation projects for social development sponsored by Brazil as examples of SSC. More specifically, BNDES credit lines for boosting South American countries' infrastructure could be seen as a kind of SSC, an example of GSI modality, since:

\footnotetext{
- It provides "a relevant economic disbursement envisaging vital areas of development in the receptor countries";

- It is "favorable to receptor countries" by presenting lower interest rates and varied means of payment;

- It also reduces expressively the "real risks to the enterprises involved" by reducing the risks of default.
}

Not being the objective of this article to engage in a conceptual debate about SSC, though, we decided to label the policy Brazil has implemented towards its South American neighbors mostly during the Lula government as regional cooperation for development (both of technical and economic nature, excepting those initiatives involving military equipment of any kind). In so doing, our aim was to get away both from the Brazilian official statements, which at times contradict the governmental practices, and from any other definitions which 
unwittingly succumb to the latter; we also wanted to avoid embracing definitions that could immerse ourselves in endless political contentions, without furthering the exam of Brazilian regional leadership, which is the core of this paper.

Having said that, amongst several examples of Brazil's new stance towards South America, we highlight some more consistent to the Brazilian cooperation for development: the support for the consolidation of the Initiative for the Integration of South American Regional Infrastructure (IIRSA); and the commitment to the Union of South American Nations (UNASUR), created in 2008.

To make both initiatives possible, Brazil has committed financial resources through two different institutions: one regionally based - FOCEM (Fund for MERCOSUR Structural Convergence); and other nationally based - the credit lines opened by BNDES to finance infrastructure projects developed by IIRSA or by national governments individually. Both initiatives were made possible thanks to Brazilian macroeconomic stability ${ }^{10}$. A challenge to many South American countries, macroeconomic stability has allowed Brazil to enhance its economic position in the region, as well as to achieve an international donor status, a happy encounter between the country's economic necessities and the government political will to promote regional development in South America, as will be presented below.

Created in 2004 as an institutional mechanism towards the mitigation of regional inequalities, FOCEM ${ }^{11}$ is an excellent example of Brazilian distinctive commitment to the region, particularly to the issue of regional integration. But it is BNDES credit lines that better illustrate Brazil's will to pay for the costs of helping to promote South American development by integrating it in sectors such as energy, transport and communication.

According to Schutte, in 2005 Guido Mantega, then BNDES's president, publicly stated that the bank had "incorporated into its mission this strategic objective, acting as a funding body for the integration in South America". (2012, p. 67) ${ }^{12}$. The strategy was to allow BNDES to give loans to foreign governments mainly for contracting major national contractors and engineering services such as Odebrecht, Camargo Corrêa and Andrade Gutierrez (see Table 01), to the extent that at least 35\% of the amount disbursed for each project was spent on imports of Brazilian products (MASIERO and CASEIRO, 2012, p. 16). Data collected by Masiero and Caseiro (2012, p. 16) also shows that between 2008 and 2011, US\$ 5.2 billion out of the US\$ 9.9 billion BNDES lent to foreign governments and corporations for the procurement of goods and services of Brazilian companies went to Latin American countries. Moreover, it is worth noting that the Brazilian government employed large amounts of subsidies when financing such loans, since the national Treasure captured resources in the financial market under an interest

10 It is worth remembering that this macroeconomic stability derives from the maintenance of many economic policies adopted during the previous government of Fernando Henrique Cardoso. However, during Lula's administration, those policies were conjugated with a bigger role conferred to the State as a fundamental part of economic growth. The State is understood, in this sense, as "capable of regulating the market to ensure a macroeconomic stability broader than monetary stability and, simultaneously, strengthen the market as the main producer of wealth". (MORAIS and SAAD FILHO, 2011, p. 525, our translation).

11 Brazil is responsible for depositing 70\% out of the total, Argentina 27\%, Uruguay 2\%, and Paraguay $1 \%$. Inversely, Brazil and Argentina are allowed to withdraw just $10 \%$ out of the fund, Uruguay 32\%, and Paraguay $48 \%$. Although it would not be correct to say that Brazilian commitment to FOCEM is devoid of interests, it does represent a dramatic change in the Brazilian stance towards the region, as long as it has materialized the country's decision to pay for the most part of the costs of this regional integration arrangement. To find out more about FOCEM's structure, see Brazil's Ministry of Planning, Budget and Management webpage, available at: <http://www.planejamento.gov.br/ secretaria. asp?cat=156\&sub=279\&sec=10>. Accessed: 21 Apr. 2012.

12 Although we do not have the figures for South America disaggregated from Latin America, it is worth noting that in 2007, for instance, the percentage of infrastructure projects within the total of the projects financed by BNDES reached 98\% (COUTINHO, 2009). 
rate of $11.7 \%$, and BNDES lent it under a rate of only $6 \%$. In this sense, the bank made the loans cheaper for its contractors, which was allowed by Brazilian government subsidies (LEOPOLDO, 2011). Additionally, BNDES's loans were supported by regional payment mechanisms ${ }^{13}$ that aim to reduce the transfer of capital among the countries involved (KOBLITZ, 2010a).

Table 1. Main Brazilian construction companies in South America

\begin{tabular}{|c|c|c|c|}
\hline Company & Countries & Continents & South-American Countries \\
\hline Odebrecht & 35 countries & $\begin{array}{c}\text { Central America, North America, } \\
\text { South America, Asia, Africa and } \\
\text { Europe }\end{array}$ & $\begin{array}{c}\text { Argentina, Bolivia, Chile, Colombia, } \\
\text { Ecuador, Paraguay, Peru, Urugauy, } \\
\text { Venezuela }\end{array}$ \\
\hline $\begin{array}{l}\text { Camargo } \\
\text { Corrêa }\end{array}$ & 9 countries & South America and Africa & $\begin{array}{c}\text { Argentina, Bolivia, Colombia, Ecuador } \\
\text { Peru, Suriname, Venezuela }\end{array}$ \\
\hline $\begin{array}{l}\text { Queiroz } \\
\text { Galvão }\end{array}$ & 9 countries & $\begin{array}{c}\text { Central America, South America and } \\
\text { Africa }\end{array}$ & Argentina, Chile, Peru, Venezuela \\
\hline OAS & 15 countries & $\begin{array}{c}\text { Central America, South America and } \\
\text { Africa }\end{array}$ & $\begin{array}{l}\text { Argentina, Bolivia, Chile, Colombia, } \\
\text { Ecuador, Peru, Uruguay, Venezuela }\end{array}$ \\
\hline $\begin{array}{l}\text { Andrade } \\
\text { Gutierrez }\end{array}$ & 40 countries & $\begin{array}{c}\text { Central America, South America, } \\
\text { Europe and Africa }\end{array}$ & $\begin{array}{l}\text { Argentina, Bolivia, Chile, Colombia, } \\
\text { Ecuador, Paraguay, Peru, Venezuela }\end{array}$ \\
\hline
\end{tabular}

Source: Author's own compilation based on information retrieved from companies websites in January 2013. Companies websites.

Note: In this table we can see all South American countries where these companies have already been engaged in some infrastructure project.

Although we have only selected projects related to the construction of physical infrastructure in the region, this does not mean that projects of distinct nature have not also been developed with Brazilian credit lines. They certainly have ${ }^{14}$. Nevertheless, our aim was to highlight only those which, besides incorporating the search for internationalization of Brazilian companies by contributing to the further diversification of the country's trading relations (BURGES, 2007) ${ }^{15}$, could also be seen as providers of regional public goods, even if they also provide private goods ${ }^{16}$.

The figures released by the 2010 Foreign Ministry Report, show that between 2003 and 2010, the 80 ongoing projects financed by Brazilian public credits to South America, mainly through BNDES resources (Banco do Brasil was another source of resources), totalized US\$10 billion (República Federativa do Brasil, 2010). The report also lists the countries and respective areas that benefited most:

13 The Agreement on Reciprocal Payments and Credits is an important example of such mechanisms. For more information on its definition and rules, see the Brazilian Central Bank's webpage, available at: <http://www.bcb.gov. br/?RED1-INFOCCR>. Accessed: 10 Apr. 2012.

14 For a comparison between Brazilian and Chinese support for emerging market multinationals, particularly regarding how the state policies encourage outward foreign direct investment as a domestic development strategy, see Masiero and Caseiro (2012).

15 It should, however, be noticed that the internationalization of Brazilian companies has not been initiated during Lula's government, and that the expansion of Brazilian multinationals is not a product of a governmental planning. Nevertheless, it has highly benefited from public policies after 2003 (ACTIS, 2013, p. 23).

16 For a discussion about physical infrastructure projects as regional public goods, see Araque Botero (2012). 
a. Argentina ${ }^{17}$ : gas pipeline enlargement, aqueduct building, and support for aerial transport infrastructure. Estimated costs: US $\$ 2.72$ billion. Firms: Odebrecht, OAS, Embraer;

b. Venezuela: building and enlargement of Caracas subway and building of a hydroelectric.

Estimated costs: US $\$ 1.06$ billion. Firms: Odebrecht e Alstom;

c. Bolivia: building of roads. Estimated costs: US $\$ 710$ million. Firms: OAS and Queiroz Galvão;

d. Chile: enlargement of Santiago subway and support to the road transports infrastructure.

Estimated costs: US $\$ 559$ million. Firms: Alstom e Mercedes-Benz Brasil;

e. Paraguay: building of a bridge. Estimated costs: US\$ 200 million.

We have no doubts that these projects strongly "help[ed] the diversification of Brazil's trading relations and a consolidation of South-South linkages by encouraging business to look in new directions", as said by Burges (2007, p. 1350). Indeed, these projects were quite successful in enhancing Brazilian exports from distinct sectors (ALÉM and CAVALCANTI, 2005, p. 57), not only services but also those related to building materials (ANTUNES, 2007, p.28; GALVÃO and CATERMOL, 2008, p.100; LEO, 2009) ${ }^{18}$. This is especially relevant when we observe the commercial relations amongst Brazil and its South American neighbors. Between 2002 and 2011, Brazil's exports to South America have increased 504\%, jumping from US\$ 7.4 billion to US\$ 45.2 billion $^{19}$. The continent constitutes a strategic trading partner in the sense that it absorbs mainly Brazilian manufactured goods, contributing to the value aggregation of Brazilian exports:

Table 2. Manufactured goods as percentage of Brazilian total exports to South American countries (\%)

\begin{tabular}{cccccccccccc}
\hline $\begin{array}{c}\text { Years/ } \\
\text { Countries }\end{array}$ & 2002 & 2003 & 2004 & 2005 & 2006 & 2007 & 2008 & 2009 & 2010 & 2011 & 2012 \\
\hline Argentina & 85.4 & 89.4 & 91.3 & 92 & 91.8 & 93 & 90.7 & 94.8 & 90.9 & 89.9 & 91 \\
Bolivia & 89 & 88.4 & 90.7 & 92.8 & 91.1 & 92.7 & 95.2 & 96.1 & 97 & 95.6 & 96.8 \\
Chile & 80.5 & 76.5 & 76 & 79.1 & 67.6 & 64 & 65.2 & 76.1 & 68.5 & 52.7 & 63.9 \\
Colombia & 93.4 & 93.5 & 89.5 & 88.7 & 97.9 & 91.2 & 88 & 83.7 & 86 & 86 & 87.2 \\
Ecuador & 93.2 & 88.3 & 91.8 & 87.6 & 89.5 & 89.5 & 95.5 & 92.7 & 92.6 & 90 & 85.8 \\
Paraguay & 96.1 & 96.6 & 96 & 93.1 & 95.7 & 95.2 & 94.7 & 92.3 & 93.4 & 92.3 & 92.4 \\
Peru & 96.1 & 90.6 & 88.1 & 82.8 & 72 & 78.7 & 80 & 74.9 & 83.4 & 81.9 & 84.1 \\
Uruguay & 79.4 & 80 & 82.2 & 86.8 & 86.1 & 88.1 & 90.4 & 89.3 & 88 & 86.3 & 80.4 \\
Venezuela & 93.7 & 92.1 & 88.6 & 89.6 & 87.3 & 82.9 & 69.3 & 66.4 & 52.4 & 55.1 & 64.9 \\
\hline
\end{tabular}

Sources: Author's own elaboration based on data provided by World Trade Organization (WTO), Brazilian Foreign Trade Association (2012) and Ministry of Development, Industry and Foreign Trade of Brazil (MDIC).

17 Argentina has been one of the countries that most benefited from Brazilian infrastructure financing in South America (KOBLITZ, 2010a). In the years 2009 and 2010, for instance, infrastructure projects in the country absorbed more than 50\% of BNDES's loans to South America. The Brazilian bank possesses a financing portfolio especially for Argentina's infrastructure projects, which is divided in three areas: gas pipelines, transports and sanitation (KOBLITZ, 2010b).

18 As an example, Odebrecht is responsible for the insertion of circa 1.600 Brazilian suppliers of different sectors in several South American countries as well as in other continents (GAIO, 2012, p.14).

19 Data released by the Ministry of Development, Industry and Foreign Trade of Brazil. For more information, see: <http://aliceweb2.mdic.gov.br/>. 
Certainly, BNDES credit lines for boosting infrastructure projects conducted by Brazilian enterprises in South American countries are not free of criticism. Such criticism arises from different sources. Following a liberal standpoint, BNDES support for few enterprises represents an excessive state intervention in economy, causing market distortions (FRIEDLANDER and TEREZA, 2009). Besides, according to representatives of Brazilian industry, the bank has benefited only a few large enterprises, excluding small and medium firms (PEREIRA, 2010). There is also an important vector of criticism concerning social and/or environmental impacts of infrastructure projects, to say nothing about the allegations of a likely imperialist behavior by the Brazilian government in South America (COSTAS, 2012; JESUS, 2012).

It is not our aim to scrutinize these criticisms. As well explained by Actis (2012), Brazil's cooperation in South America envisages not only the region's development, butalso Brazil's own developmentgoals. The author adds that the expansion of Brazil's multinationals in the continent has been understood by Brazilian government as both an instrument of national development, and regional cooperation for boosting neighbor's countries development and infrastructure. Certainly, this difficult equilibrium between "development and solidarity", as coined by the author himself, brings considerable challenges to Brazil's cooperation and leadership in South America. According to Actis (2012), however, "solidarity" has predominated over national interests and development goals when it comes to Brazil's foreign policy in the region.

We would like to add that although the benefits might also be private and to some extent asymmetricalbetween thepartner-countries, the countriesbenefitted bythecreditlinesopened up by BNDES perceived this deal as an opportunity to help them solving their own problems of development, since they assist these countries in reducing their infrastructure deficits. In this sense, despite all the challenges and contradictions, South American governments continued to countonBrazilianenterprisesandBNDESfinancialsupportwhenimprovingtheirinfrastructure.

Certainly, infrastructure projects financed by BNDES and conducted by Brazil's construction companies in South America have a great dimension and sometimes face an adverse reaction by indigenous communities, especially after the end of Lula's government. In 2011, during Dilma Rousseff's government, Odebrecht, for instance, decided to cancel a project for the construction of a hydroelectric in Peru due to pressure from local communities. Another example is the case of OAS in Bolivia in 2011, where president Evo Morales was compelled by indigenous movements to suspend part of the construction of a highway financed by BNDES ${ }^{20}$. However, it is important to keep in mind that, despite some domestic opposition from interest groups, South America's countries continued to count on Brazilian enterprises and financing for developing infrastructure projects - conflict being the exception, not the rule. In Peru, for instance, Odebrecht continues to be a major player in infrastructure projects, being in charge of many and diverse public concessions (PUPO, 2012). By its turn, OAS remains present in Bolivia through offices and projects, as informed by the Brazilian construction company ${ }^{21}$. Even the litigious dispute between the Ecuadorian government and the Brazilian construction company Norberto Odebrecht in the year of 2008 - by far the most challenging episode on Brazil's cooperative policies for boosting South American infrastructure $-{ }^{22}$ was not enough to impede further projects 
in this country to be financed by BNDES. In the end of 2012, the Ecuadorian government decided to build a new partnership with Brazil for the construction of another hydroelectric. Manduriacu hydroelectric is to be built by Odebrecht, the same company involved in the conflict of 2008, and will, once again, enjoy a US\$90.2 million credit line from BNDES ${ }^{23}$. Ecuador's ambassador in Brazil stated that "Brazilian construction companies traditionally conducted good projects" ${ }^{24}$ in the country. The ambassador added that, despite the 2008 conflict, Ecuador intends to appeal to BNDES's financial support more often, especially in the financing of irrigation projects to be carried out by Brazilian enterprises (SERODIO, 2012).

The willingness of the Ecuadorian government to rebuild such partnership with the Brazilian government and Odebrecht despite the 2008 conflict - the only one of this kind in the period ${ }^{25}$ - could be taken not only as an indicator of regional acceptance of Brazilian leading role in promoting development through this kind of enterprise, but also that Brazilian financial support for infrastructure projects in South American countries can be very useful in the eyes of neighbor governments despite all of its alleged contradictions.

However, it is not only at the economic realm that Brazil has been showing its new approach to the region. Borrowing Dauvergene and Farias (2012, p. 905) views regarding power, leadership can also come from different sources, and therefore, can likewise be exerted through cooperative mechanisms. In this sense, it is to the role of technical cooperation projects on matters of social development, agriculture, education and health that we now turn, to see how they have contributed to the deepening of Brazilian commitment to the region. Indeed, these initiatives - of which Brazil has been the biggest promoter - were important assets for sustaining and enhancing the cooperation amongst its members by creating convergences and partnerships of strong path dependence, and a distinct Brazilian leading role.

Collecting accurate data regarding such cooperative policies implemented by Brazil in South America, however, does not constitute an easy task. One of the major challenges when evaluating Brazilian cooperation for development policies is having access to accurate statistical information regarding the financial resources employment especially data related to the amount of resources actually employed in each cooperation project and to the resources employed in each receptor country. Although a few

Rafael Correa decided to expel Odebrechtand took the case to an international arbitrage court. Correa stated that the country was not planning to pay for the US $\$ 243$ million provided by BNDES for the project. As a consequence, relations between Ecuador and Brazil got strained and BNDES no longer financed new infrastructure projects in the country. According to Actis (2012), such episode constitutes an exception in Brazil's posture concerning conflicts involving Brazilian private enterprises and South American governments, given Brazil's choice to protect Odebrecht investments over preserving bilateral relations with Ecuador. In the beginning of 2009, Correa paid its full debt and bilateral relations got at ease. Brazil and Ecuador cooperation for infrastructure projects would be resumed a couple of years later.

23 For more information, see: Brasilvuelve a financiar obra local. El Universo, 13/11/2012. Available at: <http:// www.eluniverso.com/2012/11/13/1/1355/brasil-vuelve-financiar-obra-local.html>. Accessed: 14 Nov. 2012.

24 As quoted by Valor Econômico. For more information, see: Serodio, Guilherme (2012). BNDES assina financiamento de US\$ 90,2 milhões para obra no Equador. Valor Econômico, 14 Nov. 2012 Available at: <http://www. valor.com.br/internacional/2904994/bndes-assina-financiamento-de-us-902-mi-para-obra-no-equador>. Accessed: 29 Aug. 2013.

25 Although illustrative of the line adopted by the Brazilian foreign policy to bear the costs of regional asymmetry, the cases of the nationalization of hydrocarbons in Bolivia in 2006 that hit Petrobras and was settled through a conciliatory action by the Brazilian government, and the one involving Brazil's decision to meet the demands of the Assunção government to renegotiate the Itaipu agreement in 2009, would not fit as examples here since they did not involve the type of financing agreement with BNDES that we are examining. 
government agencies have offered a valuable contribution in gathering and processing official data in this area ${ }^{26}$, it is still very difficult to find consolidated numbers that could allow us a more precise referencing. In face of this gap, the Ibero-American General Secretary (SEGIB) has been making a formidable work through its annual reports on SSC, in monitoring the flow of financial resources inherent to these cooperative policies.

In this sense, according to an annual report launched by SEGIB, since 2010 Brazil has been the main responsible for cooperation projects in South America, when it exceeded the projects offered by Cuba and Venezuela, the leading countries in the offering of cooperation projects in 2009 (XALMA, 2010, 2011, 2012). In 2011, the country provided nearly 210 cooperation projects, followed by 120 projects provided by Argentina (Ibidem). In the same year, Brazil responded for $35 \%$ of all projects executed in the region and provided 75 of the total 192 cooperation projects of social dimension in South America. Concerning projects that envisaged services and infrastructure sectors, Brazil was responsible for 26 in a total of 69 projects. It is worth noting that, although Argentina also plays a relevant role in regional cooperation, the country only exceeds Brazil when it comes to cooperation actions, not cooperation projects. According to the same report, cooperation actions such as seminars and short courses on professional capacitation are more punctual, less complex and less expensive than cooperation projects. Otherwise, cooperation projects tend to involve more costs and envisage the long term. In this sense, while cooperation projects tend to subsist for about a year and a half, cooperation actions normally last a little more than one month.

Table 03 below presents an estimate of the economic disbursement carried out by offering countries, Brazil being the leading one:

Table 3. Manufactured goods as percentage of brazilian total exports to South American countries (\%)

\begin{tabular}{cccccc}
$\begin{array}{l}\text { Offering } \\
\text { country }\end{array}$ & Receptor country & $\begin{array}{c}\text { Number of } \\
\text { projects }\end{array}$ & $\begin{array}{c}\text { Share of projects } \\
\text { covered on this } \\
\text { table (\%) }\end{array}$ & $\begin{array}{c}\text { Economic } \\
\text { disbursement } \\
\text { (US\$) }\end{array}$ & $\begin{array}{c}\text { Average } \\
\text { economic } \\
\text { disbursement } \\
\text { per project (US\$) }\end{array}$ \\
\hline & Bolivia & 4 & 100 & 35,799 & 8,950 \\
& Colombia & 4 & 100 & 38,379 & 9,595 \\
Argentina & Cuba & 10 & 100 & 11,577 & 5,789 \\
& El Salvador & 1 & 100 & 57,815 & 5,782 \\
& Guatemala & 4 & 100 & 19,306 & 19,306 \\
& Nicaragua & 5 & 75 & 29,752 & 9,917 \\
& Paraguay & 12 & 11,228 & 11,228 \\
& Peru & 5 & 100 & 41,626 & 12,669 \\
\hline Argentina's Total & Dominican Rep. & 3 & 67 & 9,201 & 8,325 \\
\hline
\end{tabular}

26 One of the mostrelevant amongst such governmental agencies is the Institute for Applied Economic Research (IPEA), which is associated to the Secretariat for Strategic Affairs of the Presidency. For more information, see IPEA (2010). 
Table 3. (Continuation)

\begin{tabular}{|c|c|c|c|c|c|}
\hline $\begin{array}{l}\text { Offering } \\
\text { country }\end{array}$ & Receptor country & $\begin{array}{c}\text { Number of } \\
\text { projects }\end{array}$ & $\begin{array}{l}\text { Share of projects } \\
\text { covered on this } \\
\text { table }(\%)\end{array}$ & $\begin{array}{c}\text { Economic } \\
\text { disbursement } \\
\text { (US\$) }\end{array}$ & $\begin{array}{c}\text { Average } \\
\text { economic } \\
\text { disbursement } \\
\text { per project (US\$) }\end{array}$ \\
\hline \multirow{16}{*}{ Brazil } & Argentina & 6 & 100 & 745,276 & 124,213 \\
\hline & Bolivia & 12 & 83 & $1,923,633$ & 192,363 \\
\hline & Colombia & 20 & 75 & $2,367,119$ & 157,808 \\
\hline & Costa Rica & 11 & 91 & 651,807 & 65,181 \\
\hline & Cuba & 10 & 100 & $1,173,270$ & 117,327 \\
\hline & El Salvador & 29 & 90 & $9,495,877$ & 365,226 \\
\hline & Guatemala & 1 & 100 & $9,115,235$ & $9,115,235$ \\
\hline & Mexico & 10 & 90 & 803,274 & 89,253 \\
\hline & Nicaragua & 13 & 54 & $1,091,360$ & 155,909 \\
\hline & Panama & 5 & 100 & 478,371 & 95,674 \\
\hline & Paraguay & 14 & 43 & $2,131,106$ & 355,184 \\
\hline & Peru & 11 & 73 & 883,546 & 110,443 \\
\hline & Dominican Rep. & 13 & 100 & 686,686 & 52,822 \\
\hline & Uruguay & 7 & 71 & $1,613,287$ & 322,637 \\
\hline & Venezuela & 9 & 100 & $1,099,281$ & 122,142 \\
\hline & Others & 7 & & & \\
\hline Brazil's Total & & 178 & 79 & $34,259,128$ & 244,708 \\
\hline \multirow{9}{*}{ Chile } & Bolivia & 9 & 56 & 217,642 & 43,528 \\
\hline & Colombia & 1 & 100 & 9,752 & 9,752 \\
\hline & Costa Rica & 1 & 100 & 3,785 & 3,785 \\
\hline & Cuba & 1 & 100 & 15,413 & 15,413 \\
\hline & Ecuador & 5 & 80 & 144,467 & 36,117 \\
\hline & Guatemala & 1 & 100 & 5,704 & 5,704 \\
\hline & Mexico & 2 & 50 & 305,599 & 305,599 \\
\hline & Paraguay & 3 & 100 & 22,379 & 7,460 \\
\hline & Others & 3 & & & \\
\hline Chile's Total & & 26 & 64 & 724,741 & 42,632 \\
\hline \multirow{4}{*}{ Colombia } & Guatemala & 1 & 100 & 668 & 668 \\
\hline & Honduras & 5 & 100 & 6,342 & 1,268 \\
\hline & Peru & 3 & 33 & 797 & 797 \\
\hline & Others & 13 & & & \\
\hline Colombia's Total & & 22 & 32 & 7,807 & 1,115 \\
\hline
\end{tabular}


Table 3. (Continuation)

\begin{tabular}{|c|c|c|c|c|c|}
\hline $\begin{array}{l}\text { Offering } \\
\text { country }\end{array}$ & Receptor country & $\begin{array}{c}\text { Number of } \\
\text { projects }\end{array}$ & $\begin{array}{l}\text { Share of projects } \\
\text { covered on this } \\
\text { table }(\%)\end{array}$ & $\begin{array}{c}\text { Economic } \\
\text { disbursement } \\
\text { (US\$) }\end{array}$ & $\begin{array}{c}\text { Average } \\
\text { economic } \\
\text { disbursement } \\
\text { per project (US\$) }\end{array}$ \\
\hline \multirow{13}{*}{ Mexico } & Bolivia & 7 & 71 & 23,517 & 4,703 \\
\hline & Brazil & 5 & 80 & 54,483 & 13,621 \\
\hline & Chile & 2 & 100 & 8,705 & 4,352 \\
\hline & Costa Rica & 14 & 71 & 74,825 & 7,483 \\
\hline & Cuba & 3 & 68 & 6,406 & 3,203 \\
\hline & Ecuador & 7 & 71 & 14,738 & 2,948 \\
\hline & El Salvador & 8 & 37 & 5,549 & 1,850 \\
\hline & Guatemala & 13 & 69 & 19,300 & 2,145 \\
\hline & Nicaragua & 18 & 6 & 3,961 & 3,962 \\
\hline & Panama & 2 & 100 & 3,134 & 1,567 \\
\hline & Peru & 2 & 50 & 1,652 & 1,653 \\
\hline & Uruguay & 2 & 100 & 8,473 & 4,237 \\
\hline & Others & 6 & & & \\
\hline Mexico's Total & & 89 & 52 & 224,743 & 4,886 \\
\hline TOTAL & & 372 & 68 & $35,632,126$ & 140,248 \\
\hline
\end{tabular}

Sources: Author's own elaboration based on data provided by World Trade Organization (WTO), Brazilian Foreign Trade Association (2012) and Ministry of Development, Industry and Foreign Trade of Brazil (MDIC).

In light of these figures, we would like to underline that from 2003 to $2012^{27}$, Brazil has promoted more than 400 cooperation projects in South America. Most of these projects are mainly related to cooperation and transfer of knowledge in different sectors, such as health, fishing, agriculture, industry and energy. And many of them tend to share with other countries Brazilian national experiences in such sectors, both for bilateral and multilateral projects. Countries like Peru, Paraguay, Bolivia and Colombia were amongst the ones most beneficiated by Brazilian cooperation projects. Respectively, these countries have engaged in 76, 71, 68 and 53 projects with Brazil between 2003 and 2012.

In the case of Peru, the projects presented different purposes, like eradication of child labor, improvement of the country's health system and transfer of knowledge in the elimination of extreme poverty and hunger. Bolivia, for instance, received Brazilian assistance in improving the country's fishing sector as well as in labor capacitation for the biofuels sector and in the fight against hunger. Brazil also helped the Colombian health sector, mainly in issues concerning food and nutritional security. Likewise, Paraguay enjoyed Brazilian cooperation in the educational system, in the improvement of skilled labor for the energy sector, in the agrarian reform process, among others.

Health and agricultural sectors have shown themselves to be more prominent in Brazilian technical cooperation towards South America. Concerning the health sector, one of the best examples of Brazil's commitment to the region is its participation at the South American Health

27 The following official figures about Brazil's technical cooperation projects with South American countries were made available on our request by the Brazilian Cooperation Agency (Agência Brasileira de Cooperação/ABC), thanks to the endeavor of Luciano Barbosa de Lima from the ABC/South, Central America and Caribbean Division, in December 2012. 
Council, also known as UNASUR-Health, in which the country plays a central role. Created on December 2008, UNASUR-Health is a permanent council constituted by the Health Ministers of the UNASUR member countries, seeking to constitute a space of integration concerning health by promoting common policies and coordinating activities among its members ${ }^{28}$. The Council addresses five main issues: Health Surveillance and Response, Development of Universal Health Systems, Health Promotion and Action on Social Determinants, Universal Access to Medicines and Development of Human Resources Management. Brazil takes part at this Council mainly by the biomedical research and public health institute Fiocruz (Osvaldo Cruz Foundation), one of the most active and prominent institutions acting on human resources training and immunization. Fiocruz has indeed been an important instrument for enhancing Brazilian protagonism in the region ${ }^{29}$.

As for Brazilian technical cooperation in the agriculture sector, it is important to note the relevant role of EMBRAPA (Brazilian Agricultural Research Corporation), which has been involved in more than 70 cooperation projects in South America. It has been present in countries such as Bolivia, Paraguay, Uruguay, Peru, Guyana, Colombia, Argentina, Suriname, Ecuador and Venezuela. Its programs cover diversified areas, like food and nutritional security, soybean production, fish farming, family farming, livestock orientation, cotton production, potato production and commercialization chains, among others (SOUZA, 2010).

Altogether, those projects materialize direct transfer of knowledge and expertise that have been generated and successfully implemented within Brazil (BURGES, 2012, p. 227). Moreover, they are good examples to illustrate the way by which Brazil was quite successful in crafting a kind of regional leading role able to bring, even if asymmetrically, economic and social benefits for both itself and its neighbors.

It is on this aspect that the Brazilian portfolio of cooperation in South America favors the spread of the Brazilian development model (AYLLÓN, 2012, p. 198), to the extent that it offers a cluster of experiences, public policies and knowledge of its own (Idem), as well as professional qualification. In doing so, Brazil cooperation projects for development bring with them a Brazilian view, a Brazilian expertise and a Brazilian modus operandi, and, therefore, it crafts a kind of leadership that we label Development Leadership ${ }^{30}$.

Despite all these and many others examples that bring a positive stance to Brazil regarding its regional partners, we had examples of stumbling blocks in the Brazilian capacity to lead its regional fellows for the country's global objectives: the lack of support from Argentina to the Brazilian candidacy to the UNSC permanent seat; and the failure, in 2009, to get support from Mercosur members for Brazilian candidacy to the post of director-

28 Available at: <http://www.isags-unasul.org/interna.asp?idArea=37\&lang=2\&idPai=>. Accessed: 6 December 2012.

29 Ex-presidente da Fiocruz destaca importância do Unasul Saúde para América do Sul. Interview with Paulo Buss, 23/10/2009. Available at: <http://www.ensp.fiocruz.br/portal-ensp/informe/site/materia/detalhe/18861>. Accessed: 6 Dec. 2012.

30 We have no doubts that Brazil is also being able to craft another kind of important leading role in the region - or inwards regional leadership, as we mentioned above - by means of attitudes towards political stability in the region, such as its role on the negotiations amongst Colombia, Ecuador and Venezuela over the killing of a FARC leader by the Colombian armed forces within the Ecuadorian territory (VIEIRA \& ALDEN, 2011, p. 516); or on the Venezuelan crisis over the right of president Chavez taking office despite his illness. "Maduro: Dilma respalda decisão tomada por Judiciário”. 0 Globo, 10 Jan. 2013, Available at: <http://oglobo.globo.com/mundo/maduro-dilma-respalda-decisaotomada-por-judiciario-7246902>. Accessed: 10 Jan. 2013. Nevertheless, in this article our aim is to highlight its role as a development leader in the region, in relation to which these actions cannot be taken as examples. 
general of the WTO being two remarkable ones. Both examples illustrate quite clearly the decision of Brazil's neighbors not to behave in a quid pro quo style: despite accepting the country's leading regional role for development (inwards regional leadership) derived from the credit lines for infrastructure projects and from the supply of expertise on capacity building by means of projects of technical cooperation, they do not take it as a passport for Brazil acting in their name outside the region ${ }^{31}$. In summary, it is possible to see that Brazil's regional peers tended to maintain their own positions in global matters despite their acquiescence before Brazilian prominent cooperation projects and infrastructure financing in the regional scope. It is here that extra-regional coalitions, such as IBSA, have helped Brazil to put in practice its search for protagonism globally, this time together with its Southern partners from Asia and Africa.

\section{Brazil and the southern coalition for global protagonism}

Created in 2003, IBSA Forum (India/Brazil/South Africa Dialogue Forum) was conceived as a strategic partnership amongst emerging industrialized economies and democracies. Soon after its launching, the initiative was "transformed into a South-South inter-state cooperation based largely on soft power assets (...) articulating common goals, positions and values in world politics and economics" (HIRST, 2011, p. 3) ${ }^{32}$. In 2004, the creation of the IBSA Fund (IBSA Facility for Poverty and Hunger Alleviation) gave more credibility to the commitment of its members to enhance South-South cooperation towards the mitigation of poverty and hunger ${ }^{33}$.

Based on a common political identity crafted by their alleged "common experience with colonialism or imperialism and the social and economic inequalities that came with it and accentuated over time" (VIEIRA and ALDEN, 2011, p. 509), besides their common worries about a wide range of subjects (Idem, p. 508), IBSA is strongly committed to the promotion of matters of positive value for developing countries, contributing to bring this coalition to the category of a new pattern of Southern collective behavior in the international system. By way of example, we can mention IBSA claims for the democratization of global authority fora, including the reform of the UN, IMF and World Bank; its continuous efforts towards the promotion of a global alliance for development within the $8^{\text {th }}$ Millennium Objective; its search for the implementation of social public policies towards the control of poverty; besides sponsoring other initiatives for international cooperation for development.

31 It is worth noting that, differently from the last contest for the position of director-general of the WTO (2009), when Uruguay presented its own candidate to run against the Brazilian one, in 2013 Brazil was the only South American country to run for the position. Moreover, the regional support that Roberto Azevedo, the Brazilian candidate, received to be elected as WTO director-general last year can be seen as a sign that Brazil is succeeding to gain stronger South American support, and also as an indicator of the increasing international recognition of Brazil as a leading country on trade negotiations.

32 It is worth noting that, differently from the last contest for the position of director-general of the WTO (2009), when Uruguay presented its own candidate to run against the Brazilian one, in 2013 Brazil was the only South American country to run for the position. Moreover, the regional support that Roberto Azevedo, the Brazilian candidate, received to be elected as WTO director-general last year can be seen as a sign that Brazil is succeeding to gain stronger South American support, and also as an indicator of the increasing international recognition of Brazil as a leading country on trade negotiations.

33 For more information about IBSA Fund, see <http://www.ibsa-trilateral.org//index.php?option=com _ content\&task=view\&id=29\&Itemid=40>. 
In doing so, IBSA was a special forum for advocacy for the developing world, and could therefore be seen as a soft balancing strategy (PAPE, 2005) aiming to challenge international norms, rules or practices that might adversely affect the interests of its members, and - hopefully - to eventually change these norms. Amongst its achievements in coordinating positions on multilateral negotiations, we can mention the negotiations at the WTO (CHAKRABORTY and SENGUPTA, 2006) ${ }^{34}$; its continuous voicing for a distinct approach for international cooperation for development ${ }^{35}$; the joint project presented to the UN Human Rights Council about access to medicines and the right to medical treatment, the approval of which could be interpreted as an example of success of the political SS cooperation towards development (AYLLÓN, 2012, p. 196); as well as the demands for a new regulation of transnational capital flows (STEPHEN, 2012, p. 304). Amongst other initiatives, those above mentioned gave IBSA the status of one of the most relevant coalitions of Southern countries to act towards the building of an emerging world order.

Brazilian commitment to IBSA during Lula's government has been underlined by several authors as one remarkable example of the country's decision to choose the international coalitions of emerging countries as a central strategy of its foreign policy towards a better equilibrium in the international system (ONUKI and OLIVEIRA, 2012; VAZ, 2012; VIGEVANI and CEPALUNI, 2007). The very fact that IBSA is a partnership of large developing nations, which holds the UNSC reform amongst its main demands, illustrates the Brazilian strategy to look for other partners to strength its demands, instead of linking its regional policy with this trade-off. Moreover, Brazil did not play the role of representative of IBSA's regional partners, which released Brasilia for having previously regional negotiations and for bringing eventual demands from its regional peers to the bloc, an attitude which could have easily harmed Brazil's own interests at IBSA, without actually guaranteeing any gains for its regional neighbors. On the other side, Brazilian commitment to regional cooperation devoid of a quid pro quo behavior towards the global scenario also contributed to the image of Brazil not performing an instrumental regional-global role. And it is exactly this aspect that made Brazilian initiatives in South America and the country's commitment to IBSA Forum complementary, though not dependent on one another, as we will develop on the following and concluding session.

\section{Conclusion}

During Lula's government, Brazilian diplomacy left behind the belief that for having global protagonism the country had to make use of South America as a regional launching platform. Put differently, Brazil did not play the regional card to achieve global aims. And this is so not because the Brazilian strategy towards the global arena had changed, but mainly because Brazilian regional aims were modified. In other words, Brazilian policy of giving priority towards South America was an objective in itself in the direction of a better relationship with its neighbors. As a matter of fact, by comparing the time when Brazil used to look at initiatives of regional integration such as Mercosur as a tool to enhance its role on

34 It is worth quoting former Brazilian Ministry of Foreign Affairs, Ceslo Amorim, who said that "I can state with conviction that the G-20 would not exist without IBSA" (Celso Amorim, "The India-Brazil-South Africa Dialogue Forum and World Trade", in The India-Brazil-South Africa Dialogue Forum, (Brasilia: Ministry of External Relations, Republic of Brazil, 2006), p. 6. Apud STEPHEN, 2012, p, 300).

35 IBSA Trilateral Forum, "Fourth Summit of Heads of State/Government Brasilia Declaration", April 2010, Available at: <www.ibsa-trilateral.org.>, p. 5. Accessed: 4 Dec. 2012. 
global politics in a kind of regional-global duplicity performance (PINHEIRO, 2000, p. 327) to the period 2003-2010 approximately, we notice that Brazilian commitment to South American development then did express a different approach towards the region - more prone to collective development as part of Brazilian national interests. In this sense, we argue that Brazil did exercise a regional leadership, but one of a different kind and for distinct purposes. In other words, we should not see leadership as a comprehensive concept - that is, one that could cover all dimensions of a country's interests whichever the forum of discussion - nor as an instrument or credential for acting outside the regional sphere, but rather as the capacity to influence South American neighbors on matters of regional governance due to the outstanding impact that Brazilian "capacity development ${ }^{36 "}$ projects of international cooperation had on modeling regional development. It is worth noting that we are not talking about the victory of one kind of development model over its rivals (desenvolvimentismo over liberalism), but rather about one way of boosting regional development by means of credit lines for infrastructure projects as well as by means of public financing of technical cooperation projects that aim at economic stability and social progress in collective terms. Naturally, we are not unaware about the existence of competing ideological positions in the region as well as some level of opposition to the mode of development leadership searched by Brazil. Nevertheless, we state that despite some level of opposition and dispute, Brazil was able to maintain its leading position in the region both as an infrastructure projects provider of funds and as a pattern of how to make them feasible ${ }^{37}$.

The kind of leadership Brazil has performed was very much of a collaborative and distributive nature, to pick up two patterns of leadership mentioned by Tokatlian (2010). It is so in the sense that Brasília showed great inclination for sharing resources and for paying the costs for regional development and, in doing so, contributing for the social and economic development of neighbors in the name of a stronger regional stability and governance. Nevertheless, to say that Brazil was playing such a leading role on the regional sphere does not mean that the country did so devoid of interests. In other words, initiatives like those we cited above did help the country to enhance political links in the region and also brought benefits for Brazilian private investments, especially for the sectors which are brought to the scene as suppliers of goods and services, as well as for Brazilians living in South America countries (SPEKTOR, 2010, p. 36). In doing so, two important consequences followed: firstly,

36 Brazil actually calls it as "cooperação estruturante para o desenvolvimento", which is a little different from UNDP's definition of capacity development. Whilst for Brazil the "cooperação estruturante para o desenvolvimento" means the construction of capacities for development by integrating the human resources formation, organizational strengthening, and institutional development, besides refusing to replicate the traditional unilateral transference of technologies; or "proyectos creadores de capacidades nacionales con impacto social y económico sobre los beneficiarios que movilizan agentes de varias áreas y aseguran más apropiación y sostenibilidad" (AYLLÓN, 2012, p. 200); or yet a kind of assistance based on a 'structural' approach, that is, "a sustainable plan of action to reach longterm socioeconomic impact on the ground"(HIRST, 2011, p. 05); for UNDP, "capacity development" "builds on this evolution and has three cornerstones. It is a continuing learning and changing process. It emphasizes better use and empowerment of individuals and organizations. And it requires that systematic approaches be considered in devising capacity development strategies and programmes". UNDP-UNITED NATIONS DEVELOPMENT PROGRAMME. Capacity Development: Technical Advisory Paper No. 2. Management Development and Governance Division, Bureau for Policy Management, New York. 1997, 89 pp. Available at: <http://mirror.undp.org/magnet/Docs /cap/Capdeven. pdf.> Accessed: 12 May 2012.

37 It is worth mentioning that Chile, Colombia, Peru, all members of the Pacific Alliance, have also signed contracts with BNDES for financing infrastructural projects. See Brasil Econômico (redação@brasileconomico. com.br), 17/10/11; By Business News Americas staff reporter - Thursday, October 27, 2005; http://www.valor.com. br/politica/2603590/megaprojeto-brasileiro-no-peru-sai-do-papel\#ixzz2bZABo0zR; http://www.valor.com.br/ empresas/2598548/odebrecht-assumira-100-de-gasoduto -no-peru\#ixzz2bZBOd8Id. 
Brazilian government helped some of its big companies to internationalize and, at the same time, contributed to provide regional public goods that helped to boost regional development; and secondly, the government succeeded in articulating private domestic and public external interests much better by promoting a domestic constituency for the continuation of this policy, though it also brought some level of dissatisfaction from sectors that did not benefit from the same policy, or from those who disagreed with the criteria used to choose the benefited companies (MASIERO and CASEIRO, 2012, pp.30-31). As we have already shown, the infrastructure sector absorbed a large part of Brazilian government support ${ }^{38}$, which contributed to its expansion in South America and in other parts of the world as well.

On the other hand, despite the acceptance of Brazil's inwards regional leadership by its peers, Brazilian regional status could not be automatically taken as regional acceptance to represent the latter on all global matters as their leader. And it is in this track that the IBSA forum could be seen as the other part of the Brazilian aims and strategy. Since Brazil started to develop new kinds of coalitions, such as IBSA, BRICS, BASIC, there is no need to work on the regional level as a launching platform for global protagonism (VAZ, 2012). The interstate coalitions of regional powers like IBSA are important tools for making feasible the articulation of emerging countries who share the same objective of changing the present pattern of international relations towards their economic and political ascendance, since they seem to be more adequate and indeed more efficient, without high costs of transaction. In this sense, at IBSA Brazil could strengthen its condition of regional power to act in global matters, benefiting from this situation, without having to search in advance for a certificate from its regional partners to be a regional leader.

Likewise, since Brazil has gained increasing global recognition and, therefore, it does not depend on a pre-regional endorsement to do $\mathrm{so}^{39}$, the regional links might also be beneficiary of this situation. Indeed, it is not out of the question to think that this kind of intra-regional relationship without the expectation for trade-offs in global matters - either from Brazil as a paymaster or from the South American countries as beneficiaries - can indeed contribute to facilitate the relationship amongst Brazil and its neighbors, with possible positive results even for the debates at the global fora. In other words, to the extent that trade-offs are not put on the negotiation table, this relationship might slowly lead to a kind of recognition of Brazil's credentials to represent South America in global fora ${ }^{40}$. But even if that does not happen in the future, Brazil has already presented itself as regional development leader without - and definitely with no need for - bringing its neighbors to the global negotiation tables.

Nevertheless, to give rise to some speculations, we should also think about possible non-expected consequences stemming from IBSA coalition. Being part of an intermediate

\footnotetext{
38 See Table 01 above.

39 This lack of dependency between traditional regional leadership and global performance can be exemplified by the fact that, even after its defeat as candidate for WTO general-director in 2009, due to the lack of regional supporters, Brazil's reputation and influence in WTO has not been damaged (MALAMUD, 2011, p.9). Besides, we could also mention other Southern coalitions for specific issues of which Brazil is a member, in which the country - and perhaps also its partners - also benefits from its condition of regional power, without having to be a regional leader in its traditional meaning, such as BASIC (Conference of the Parties (COP) of the Framework Convention on Climate Change, created in early 2010 this coalition brings together Brazil, South Africa, India and China for matters of Climate Change;. G-4 - India, Germany, Japan, and Brazil - the articulation for the reform of the Security Council of the United Nations (UNSC).

40 It is not out of question the hypothesis that the support Brazil received from its regional peers - Argentina, Paraguay, Bolivia, and Venezuela, among others - for the Brazilian candidacy to WTO general-director is an example of that. "Azevedo Rode To WTO Victory Mainly Due To Developing World Support". Available at: <http://wtonewsstand. com/WTO-Daily-News/Daily-News/menu-id-446.html>.
} 
level within the international hierarchy, the successes of IBSA initiatives are very much based on the premises that its members do not compete for resources amongst themselves (at least not yet), and have more latitude for cooperation exactly because they are few and have many similarities. However, the new Brazilian status in Africa supported both by the internationalization of Brazilian big companies and by technical cooperation projects for development ${ }^{41}$, as well the increasing Indian presence in the continent could bring some kind of discomfort amongst these partners, therefore bringing damages to the IBSA coalition. The emergence of Brazil and India in Africa can bring some annoyance to South Africa, since the continent's Southern region has been under South African influence.

Finally, bringing the issue of regional leadership back to our discussion, we would also like to raise another question which so far has not been object of much attention: to what extent we could generalize the conclusions taken from the relationship between Brazil and its regional partners to the other IBSA members and their regional fellows. In other words, to what extent India and South Africa membership to IBSA was not also a consequence of change in their aims and/or their strategy towards their respective regional environment? Perhaps the search for responding this question could help us to improve the arguments here developed for the Brazilian case.

Revised by Natália Maria Félix de Souza Submitted in October 2013 Accepted in July 2014

\section{References}

ACTIS, Esteban (2012), Entre el desarrollo y la solidaridad. La expansión del capital brasileño y sus consecuencias para la política exterior sudamericana de Brasil (2003-2011). Boletim Meridiano, 47. Vol. 13, № 131, pp. 10-15.

ACTIS, Esteban (2013), Brazil power and multinational corporation: las empresas multinacionales brasileñas, la política exterior y la inserción internacional de Brasil. Un análisis desde los aportes de Robert Gilpin. JANUS.NET e-journal of International Relations, Vol. 4, N. 1, Maio-Outubro 2013. Accessed [online] em data da última consulta, observare.ual.pt/janus.net/pt_vol4_n1_art2.

ALÉM, A. C. and CAVALCANTI, C. E. (2005), O BNDES e o apoio à internacionalização das empresas brasileiras: algumas reflexões. Revista do BNDES. Vol. 12, № 24, pp. 43-76.

ANTUNES, A. J. C. (2007), Infraestrutura na América do Sul: situação atual, necessidades e complementaridades possíveis com o Brasil. Cepal, viewed 25 January 2012.<http://www.cepal.org/publicaciones/ xml/2/32302/LCBRSR186AntonioJoseCerqueiraAntunes.pdf >.

ARAQUE BOTERO, L. A. (2012), o Desenvolvimento Econômico e Social como Bem Público Regional: Análise do Processo de Construção da Integração Física Sul-Americana. Master Thesis, PUC-Minas, Belo Horizonte.

AYLLÓN, B. and LEITE, I. C. (2010), La cooperación sur-s de Brasil: proyección solidaria y política exterior. In: AYLLÓN, B. and SURASKY, J. (Coords.). La cooperación sur-sur em latinoamérica: utopía y realidad. Madrid: Catarata, pp. 69-102.

AYLLÓN, B. P. (2012), Contribuciones de Brasil al desarrollo internacional: coaliciones emergentes y cooperación Sur-Sur. Revista CIDOB d'afers internacionals. № 97-98, pp. 189-204.

BRAZILIAN FOREIGN TRADE ASSOCIATION (2012), Radiografia do Comércio Exterior Brasileiro. AEB, viewed 20 October 2012. http://www.aeb.org.br/userfiles/file/AEB\%20-\%20Radiografia \%20Com\%C3\%A9rcio\%20Exterior\%20Brasil.pdf

41 "In $201027.5 \%$ of the ABC budget was destined for Latin America, and 42\% for Africa" (Brazilian Cooperation Agency - Ministry of External Relations (2011) Brazilian Technical Cooperation, mimeo. Apud, HIRST, 2011, p.6). 
BURGES, S. (2005), Bounded by the reality of trade: practical limits to a South American region. Cambridge Review of International Affairs. Vol.18, № 03, pp.437-454.

BURGES, S. (2007), Building a Global Southern Coalition: The Competing Approaches of Brazil's Lula and Venezuela's Chávez. Third World Quarterly. Vol. 28, № 07, pp. 1343-1358.

BURGES, S. W. (2008), Consensual Hegemony: Theorizing Brazilian Foreign Policy After the Cold War. International Relations. Vol. 22, № 01, pp. 65-84.

BURGES, S. (2012), Developing from the South: South-South Cooperation in the Global Development Game. Austral: Brazilian Journal of Strategy \& International Relations. Vol. 01, № 02, pp. 225-249.

CHAKRABORTY, D. and SENGUPTA, D. (2006), IBSAC (India, Brazil, South Africa, China): A Potential Developing Country Coalition in WTO Negotiations, CSH Occasional Pape. № 18.

CINTRA, M. (Ed.) (2011), Brazilian Cooperation for International Development, 2005-2009. Brasília: Ipea.

COSTAS, Ruth (2012), Aos 60 anos, BNDES do século 21 atrai polêmicas e atenções internacionais. BBC Brasil. 20 Aug. 2013, viewed 29 Aug. 2013 <http://www.bbc.co.uk/portuguese/noticias/2012/08/120813 bndes_60anos_ru.shtml>.

COUTINHO, L. (2009), O BNDES e o apoio aos projetos Brasil - América Latina. BNDES, viewed 11 October 2012. $<$ http://ceal-int.org/RD/abr09/bndes.pdf.>.

DAUVERGNE, P. and FARIAS, D. B. L. (2012), The Rise of Brazil as a Global Development Power. Third World Quarterly. Vol. 33, № 05, pp. 903-917.

FLEMES, D., and WOJCZEWSKI, T. (2010), Contested Leadership in International Relations: Power Politics in South America, South Asia and Sub-Saharan Africa. German Institute of Global and Area Studies - GIGA, viewed 4 May 2013. http://www.giga-hamburg.de/dl/download.php?d=/content/publikationen/pdf/ wp121_flemes-wojczewski.pdf.

FRIEDLANDER, David; TEREZA, Irany (2009),BNDES gasta US\$ 8 bi por ano para criar campeãs nacionais. O Estadão de São Paulo, 27 set. 2009, viewed 23 Apr. 2012. http://www.estadao.com.br/noticias/ impresso,bndes-gasta-r-8-bi-em-um-ano-para-criar-campeoes-nacionais,441624,0.htm.

GAIO, G. F. F. (2012), Você Imaginou. Nós Construimos. Estado, Mercado e a Participação Brasileira na Recuperação da Infraestrutura Angolana. Monograph Work, PUC-Rio, Rio de Janeiro.

GALVÃO, B. and CATERMOL, F. (2008), Exportações de serviços e o apoio do BNDES. BNDES Setorial. № 28, pp. 73-104

HIRST, M. (2010), Hacia la construcción de un proyecto sudamericano. La Nacion, 06 November, viewed 16 February 2013. <http://www.lanacion.com.ar/1321623-hacia-la-construccion-de-un-proyecto-sudamericano>.

HIRST, M. (2011), Brazil's renewed responsibilities in cooperation for development and international security. Center on International Cooperation - New York University, viewed 30 March 2013. < http://www.reded. net.br/index.php?option=com_jdownloads\&Itemid=183\&view=finish\&cid=119\&catid=4\&lang=en>.

HIRST, Monica; SOARES DE LIMA, Maria R. and PINHEIRO, Letícia. (2010), A política externa brasileira em tempos de novos horizontes e desafios. Nueva Sociedad, Special Edition, pp. 22-41.

HURRELL, A.(2000), Some Reflections on the Role of Intermediate Powers in International Institutions. In: HURRELL, A.; COOPER, A. F.; GONZÁLEZ, G.; SENNES, R. U. and SITARAMEN, S. (2000), Paths to Power: Foreign Policy Strategies of Intermediate States. Woodrow Wilson International Center Latin American Program, pp.1-10, viewed 4 March 2013. < http://www.wilsoncenter.org/sites/default/files/ACF14A1.pdf>.

IPEA (2010), Cooperação Brasileira para o Desenvolvimento Internacional: 2005-2009. Brasília: IPEA, 62 p.

JESUS, Samuel (2012), Imperialismo brasileiro: visões jornalísticas sobre a atuação brasileira na América do Sul e no mundo. Mundorama. № 25, Sep. 2012, viewed 29 Aug 2013. < http://mundorama.net/2012/09/25/ imperialismo-brasileiro-visoes-jornalisticas-sobre-a-atuacao-brasileira-na-america-do-sul-e-nomundo-por-samuel-de-jesus/>

KINDLEBERGER, C. (1981), Dominance and Leadership in the International Economy: Exploitation, Public Goods, and Free Rides. International Studies Quarterly. Vol. 25, № 02, pp. 242-254.

KOBLITZ, A. (2010a), O BNDES acredita nos mecanismos regionais. In: BRAGA, Brunno (Ed.), Seminário Bilateral de Comércio Exterior e Investimentos Brasil-Argentina. Rio de Janeiro: Federação das Câmaras de Comércio Exterior (FCCE), pp. 50-51.

KOBLITZ, A. (2010b), Integração bilateral positiva em pauta. In: BRAGA, Brunno (Ed.), Seminário Bilateral de Comércio Exterior e Investimentos Brasil-Argentina. Rio de Janeiro: Federação das Câmaras de 
Comércio Exterior (FCCE), pp. 18-21.

LENGYEL, Miguel and MALACALZA, Bernabé (2011), De que hablamos cuando hablamos de Coperación Sur-Sur? La construcción del concepto desde bases empíricas. In: IPSA-ECPR Joint Conference, São Paulo, Feb.

LEO, S. (2009), Exportação de serviços puxa venda de bens. Valor Econômico, № 28 September, viewed 15 April 2013. < http://www.valor.com.br/arquivo/785393/exportacao-de-servicos-puxa-venda-de-bens>.

LEOPOLDO, R. (2011), Créditos do BNDES crescem 391\% em 5 anos e já são o triplo do Banco Mundial. 0 Estado de São Paulo, 3 March, viewed 8 January 2013. <http://www.fazenda.gov.br/resenhaeletronica/ MostraMateria.asp?cod=706233>.

LIMA, M. R. S. (2005b), Aspiração Internacional e Política Externa. Revista Brasileira de Comércio Exterior. № 82, ano XIX.

LIMA, M. R. S. and HIRST, M. (2006), Brazil as an Intermediate State and Regional Power: Action, Choice and Responsibilities. International Affairs. Vol. 82, № 01, pp. 21-40.

MALAMUD, A. (2011), A Leader without Followers? The Growing Divergence between the Regional and Global Performance of Brazilian Foreign Policy. Latin American Politics and Society. Vol. 53, № 03, pp. 1-24.

MURAKAWA, F. (2011), Pressão indígena faz Odebrecht desistir de hidrelétrica no Peru. Valor Econômico. São Paulo, 24 November, 2011.

MURAKAWA, F. (2012), BNDES exige novo contrato para financiar estrada na Bolívia. Valor Econômico, São Paulo, 06 February, 2012.

MASIERO, G. and CASEIRO, L. C. Z. (2012), State Support for Emerging Market Multinationals: The Brazilian and Chinese experiences. Centro Internacional de Formación Financiera, viewed 20 Frebruary 2013. < http://www.ciff.net/attachments/publicaciondtc10.pdf>.

MORAIS, L. and SAAD-FILHO, A. (2011), Da economia política à política econômica: o novo desenvolvimentismo e o governo Lula. Revista de Economia Política. Vol. 31, № 04, pp. 507-527.

ONUKI, J. and OLIVEIRA, A. J. (2012), New role of Brazil in global governance. Presented at 53rd Annual International Studies Association Convention, San Diego, CA, April 1-4, Panel Emerging Powers in New Global Governance.

PAPE, R. A. (2005), Soft Balancing in the Age of U.S. Primacy. Internacional Security. Vol. 30, № 01, pp. 7-45.

PECEQUILO, C. S. and CARMO, C. A. (2012), Brazil and South America Regional Integration Projects: Cooperation or Power Projection? Presented at the International Political Science Association (Ipsa) 22nd World Congress of Political Science. Madrid, July 8-12.

PEREIRA, Renée (2010), Empresários reclamam de acesso difícil ao BNDES. 0 Estado de S. Paulo, 1 Aug. 2010, viewed 29 Aug., 2013. <http://www.estadao.com.br/noticias/impresso,empresarios-reclamam-deacesso-dificil-ao-bndes,588883,0.htm>.

PINHEIRO, L. (2000), Traídos pelo desejo: um ensaio sobre a teoria e a prática da política externa brasileira contemporânea. Contexto Internacional. Vol. 22, № 02, pp. 305-35.

PUPO, F. (2012), Odebrecht ganha concessão no Peru. Valor Econômico. São Paulo, 20 September, viewed 7 May 2014. < http://www.valor.com.br/empresas/2836846/odebrecht-ganha-concessao-no-peru>

REPÚBLICA FEDERATIVA DO BRASIL (2010), América do Sul: infraestrutura. Ministério das Relações Exteriores, viewed 15 April 2013. <http://www.itamaraty.gov.br/temas/balanco-de-politica-externa2003-2010/1.1.6-america-do-sul-infraestrutura/view>

SARAIVA, M. G. (2010), Brazilian foreign policy towards South America during the Lula Administration: caught between South America and Mercosur. Revista Brasileira de Política Internacional. Vol. 53, special edition, pp. 151-168.

SCHUTTE, G. R. (2012), Neo-Developmentalism and the Search of a New International Insertion. Austral: Brazilian Journal of Strategy \& International Relations. Vol.01, № 02, pp.59-93.

SERODIO, Guilherme (2012), BNDES assina financiamento de US\$ 90,2 milhões para obra no Equador. Valor Econômico. № 14, Nov. 2012, viewed 29 Aug. 2013. <http://www.valor.com.br/internacional/2904994/ bndes-assina-financiamento-de-us-902-mi-para-obra-no-equador $>$.

SILVA, A. M. (1995), O Brasil no Continente e no Mundo: Atores e Imagens na Política Externa Brasileira Contemporânea. Estudos Históricos. Vol. 08, № 15, pp. 95-118.

SOUZA, Sol M. V. (2010), A Embrapa na Política de Cooperação Sul-Sul do Brasil. Monograph Work,PUC-Rio, Rio de Janeiro.

STOLTE, C. (2012), Brazil in Africa: Just Another BRICS Country Seeking Resources? Africa Programme and Americas Programme - Chatham House, viewed 10 January 2013. < http://www.chathamhouse.org/ 
sites/default/files/public/Research/Africa/1112bp_brazilafrica.pdf>.

SPEKTOR, M. (2010), Ideias de ativismo regional: a transformação das leituras brasileiras da região. Revista Brasileira Política Internacional. Vol. 53, № 01, pp. 25-44 .

STEPHEN, M. D. (2012), Rising Regional Powers and International Institutions: The Foreign Policy Orientations of India, Brazil and South Africa. Global Society. Vol. 26, № 03, pp. 289-309.

TOKATLIAN, J. G. (2010), El desafío de definir el rol como potencia global. La Nacion, 6 November, viewed 2 May 2012 < http://www.lanacion.com.ar/1321624-el-desafio-de-definir-el-rol-como-potencia-global>.

VAN LANGENHOVE, Luk and ZWARTJES, Marieke. “Conceptualizing Regional Leadership: the Positioning Theory Angle" in Tussie, Diana \& QUILICONI, Cintia (eds) "Leadership of BRICS at the regional and global levels - Capacity, Willingness and Legitimacy in an era of Multipolarity", NY, Springer Publ. Co., Forthcoming.

VAZ, A. C. (2012), Coaliciones internacionales en la política exterior brasileña: seguridad y reforma de la gobernanza. Revista CIDOB d'afers internacionals. № 97-98, April, pp. 175-187.

VIEIRA, M. A. and ALDEN, C. (2011), India, Brazil, and South Africa (IBSA): South-South Cooperation and the Paradox of Regional Leadership. Global Governance. Vol. 17, № 04, pp. 507-528.

VIGEVANI, T. and CEPALUNI, G. (2007), A política externa de Lula da Silva: a estratégia da autonomia pela diversificação. Contexto Internacional. Vol. 29, № 02, pp. 273-335.

XALMA, Cristina (2010) Informe de la cooperación Sur-Sur en Iberoamerica 2010, Secretaría General Iberoamericana (SEGIB), viewed 15 March 2013. <http://segib.org/actividades/files/2010/12/infcoop-sur-sur-2010.pdf>.

XALMA, Cristina (2011), Informe de la cooperación Sur-Sur en Iberoamerica 2011. Secretaría General Iberoamericana (SEGIB), viewed 15 March 2013. <http://segib.org/news/files/2011/11/Informe-SurSur-2011-ESP.pdf.>.

XALMA, Cristina (2012), Informe de la cooperación Sur-Sur em Iberoamerica 2012. Secretaría General Iberoamericana (SEGIB), viewed 15 March 2013. <http://segib.org/cooperacion/files/2012/10/ Informe-Sur-Sur-2012.pdf>. 